\title{
Soil Nutrient Status and Cowpea Biological Nitrogen Fixation in a Maize-Cowpea Rotation Under Conservation Farming
}

\author{
Richard Sichone $^{1} \&$ Alice M. Mweetwa ${ }^{1}$ \\ ${ }^{1}$ Department of Soil Science, School of Agricultural Sciences, University of Zambia, Lusaka, Zambia \\ Correspondence: Alice M. Mweetwa, Department of Soil Science, School of Agricultural Sciences, University of \\ Zambia, P.O. Box 32379, Lusaka, Zambia. Tel: 260-971-803-918. E-mail: alicemweetwa@yahoo.com
}

Received: February 28, 2018

Accepted: April 13, $2018 \quad$ Online Published: May 15, 2018

doi:10.5539/jas.v10n6p136

URL: https://doi.org/10.5539/jas.v10n6p136

\begin{abstract}
This paper reports the impacts of a four-year maize-cowpea rotation under conservation farming on selected soil chemical, physical and biological properties with or without $100 \mathrm{~kg} / \mathrm{ha}$ of Nitrogen: Phosphorus: Potassium: Sulphur (10:20:10:65) compound fertilizer. The study took advantage of an already established 4-year maize-cowpea rotation site and a maize monocrop field from which soil samples were collected for selected chemical, physical and biological analyses, and for setting up a greenhouse experiment for the determination of biological nitrogen fixation capabilities of cowpea. The results suggest that maize-cowpea rotations and addition of fertilizer influence particular chemical, physical and biological attributes of the soil in a varied manner. Rotating maize and cowpea has no influence on soil reaction, soil organic carbon, micronutrients, and exchangeable bases except for potassium. However, the addition of fertilizer to the maize-cowpea rotation reduces total nitrogen, while increasing the levels of sulphur and phosphorus in both the rotation and maize monocrop. Soil bulk density, total porosity and infiltration rate are not influenced by the maize-cowpea rotation with or without fertilizer amendment. Rotating maize with cowpea without the addition of fertilizer can result in an increase in plant available water, an observation needing further study. It can also be concluded that maize-cowpea rotations can reduce microbial biomass, regardless of fertilizer amendment, thus suggesting a need to understand maize and cowpea rhizopheric attributes affecting microbial biomass levels. Under the current conditions, the amount of biologically fixed nitrogen by cowpea is reduced by the application of fertilizer but not influenced by the rotation. Since these findings are based on four-year crop rotation, it is being recommended that further work be conducted to continue monitoring soil so as to factor in the effect of length of time.
\end{abstract}

Keywords: conservation farming, rotation, biological nitrogen fixation, maize, cowpea

\section{Introduction}

To partially address productivity constraints associated with low soil fertility levels and to introduce more sustainable land management strategies, conservation farming (CF) has been promoted in Zambia through the Conservation Farming Unit since 1985 (Giller, Witter, Corbeels, \& Tittonel, 2009). CF encompasses three basic principles of minimum soil disturbance, residue retention and crop rotation with legumes (Thierfelder $\&$ Wall, 2009). The CF system seeks to improve soil structure, reduce erosion, conserve moisture, enhance soil fertility and reduce incidences of pests and diseases by taking advantage of the natural ecological processes (Zimbabwe Conservation Agriculture Task Force, 2009). In Zambia, the practice of CF includes dry-season land preparation using minimum tillage methods, nitrogen-fixing crop rotations, reduced but precise doses of mineral fertilizer and crop residue retention after harvest (CFU, 2007a, 2007b). The practice also involves seeding and input application in fixed planting stations in the form of basins or rip lines, normally made using the locally developed "Magoye" ripper pulled with animal traction. Both of these systems result in only about $15 \%$ of the soil being moved (Haggblade, Kabwe, \& Plerhoples, 2011). In general, farming systems such as CF have been shown worldwide to improve soil quality and crop yields (SWCS, 2003). Although several studies have shown that there were better crop yields under $\mathrm{CF}$, the practice alone would not adequately address the production challenges in smallholder farming systems (Nyagumbo, 2008).

Crop rotation is a systematic or recurrent sequence of crops grown over a number of cropping seasons (Reeves, 1994). This practice, compared to monocropping, would result in improved soil conditions accomplished 
through the preservation or amelioration of soil biological, chemical and physical properties (Aziz, Ashraf, Mahmood, \& Islam, 2011). Crop rotations help in nutrient distribution in the soil profile resulting in the full exploitation of the root zone with crops of differing rooting depths (Giller et al., 2009). Crop rotations that include legumes as is the case in $\mathrm{CF}$, increase the nitrogen pool through biologically fixed nitrogen. Use of legumes in rotations potentially reduces dependence on nitrogen fertilizer and is economically prudent. In addition, manipulating the diversity of cropping sequences can affect soils by changing carbon levels through the differences in the chemical composition of organic residues and root exudates that are added to the soils (Beare, Cabrera, Hendrix, \& Coleman, 1994). This in turn affects microbial biomass and important processes such as decomposition of organic matter and mediation of nutrient availability to plants.

Although there are obvious effects of rotation on soil mineral status, there are other effects of this practice not attributable to mineral status alone (Riedell, Pikul, Jaradat, \& Schumacher, 2009). In addition, no single rotation can optimize water and nutrient use, minimize disease and weed problems and optimize crop yield per hectare. This presents an opportunity to understand and acknowledge other benefits from crop rotations under $\mathrm{CF}$ and to test numerous types of rotations and plant species that may yield variable economic and environmental effects. Despite the positive effects that crop rotation offers, there is still paucity of information on the effects of crop rotation on soil chemical, physical and biological properties and their relation to crop performance under the current practice of CF in Zambia. The paper reports on the findings of measured soil quality indicators from a four-year maize-cowpea rotation system under $\mathrm{CF}$ and the contribution of nitrogen fixation of cowpea to the system.

\section{Materials and Methods}

The study took advantage of an already established 4-year maize-cowpea rotation field from which soil samples were collected for chemical, physical and biological analyses, and for setting up a greenhouse experiment for the determination of biological nitrogen fixation capabilities of cowpea.

\subsection{Site Description}

The study was carried out at the Golden Valley Agricultural Research Trust (GART), in Chisamba (latitude, $14^{\circ} 30^{\prime}$; longitude $28^{\circ} 30^{\prime}$ ) of Chibombo District in Central Province, Zambia. Chisamba is in agro-ecological region II of Zambia. This region receives between 800 and $1000 \mathrm{~mm}$ rainfall per annum. Chisamba area (altitude $1060 \mathrm{~m}$ ) receives an average annual rainfall of about $900 \mathrm{~mm}$. The area has well drained very deep, dark red to reddish brown friable, clayey to fine loamy soil with a humic top soil: Luvisol, with an average $\mathrm{pH}$ of 5.5.

\subsection{Soil Sampling}

Soil samples were collected from the permanent planting basins of an on-going maize-cowpea rotation system. Soil samples were taken from the field at the end of the second cowpea phase. Previously, at the start of the rotation cycles, both the rotation and the maize mono-crop sites had been characterized for soil reaction and exchangeable bases as follows: $\mathrm{pH}$ was 5.2 ; calcium, magnesium, potassium and sodium were $6.67,4.39,0.28$ and $0.07 \mathrm{cmol}(+) / \mathrm{kg}$, respectively.

The rotation included two fertilization rates for crops: No fertilizer or $100 \mathrm{~kg} / \mathrm{ha} \mathrm{D}$ compound (NPK $10-20-10+6.5 \% \mathrm{~S})$ as basal dressing. In total, there were four treatments that included: maize-cowpea rotation without fertilizer; maize-cowpea rotation with fertilizer; maize monocropping without fertilizer; maize monocropping with fertilizer. Eight permanent planting basins from each treatment were randomly selected and sampled to come up with a composite sample. Using a standard auger, soil sampling was done following the procedure outlined by Barker and Pilbeam (2006) from a depth of $0-20 \mathrm{~cm}$. The composite soil sample was thoroughly mixed and unwanted materials present removed and 500 grams of soil obtained for the analysis of selected chemical parameters. Additional $500 \mathrm{~g}$ of soil was collected for the microbial analysis, carried on ice in cooler boxes and then kept at $4{ }^{\circ} \mathrm{C}$ until use. All samples were collected in replicates of four.

Core ring samples and bulk soils were also obtained in replicates of four from each experimental unit for the analysis of physical characteristics and for the greenhouse determination of biological nitrogen fixation, respectively.

\subsection{Determination of Selected Chemical, Physical and Biological Properties of Cowpea}

The soil samples were analysed in replicates of four for soil pH (Mclean, 1982), total nitrogen (Bremner \& Mulvaney, 1982), available phosphorus (Olsen \& Sommers, 1982), total sulphur, soil organic carbon (Rhodes, 1982) and exchangeable bases $\left(\mathrm{K}^{+}, \mathrm{Na}^{+}, \mathrm{Ca}^{2+}\right.$ and $\mathrm{Mg}^{2+}$ ) (Thomas, 1982), cation exchange capacity (CEC), and micronutrients $\left(\mathrm{Cu}^{2+}, \mathrm{Zn}^{2+}, \mathrm{Mn}^{2+}, \mathrm{Fe}^{3+}\right)$. The samples were also characterized for soil bulk density (Core Ring 
method), total porosity, infiltration rates, plant available water, microbial counts and biomass (Kassem \& Nannipieri, 1995) and texture (Day, 1965).

\subsection{Determination of Biological Nitrogen Fixation of Cowpea and Nodulation}

Biological nitrogen fixation was determined under greenhouse conditions using the Nitrogen Difference Method (Unkovich et al., 2008). Uninoculated cowpea (Lutembwe) seeds were sown in pots containing $5 \mathrm{~kg}$ of the bulk soils described in 2.2 and obtained from maize-cowpea rotation without fertilizer, maize-cowpea rotation with fertilizer, maize monocropping without fertilizer and maize monocropping with fertilizer treatments. In addition, pearl millet (Lubasi) was planted as a non-nitrogen fixing reference crop (Munyinda, Yamba, \& Walimwipi, 2012). The experiment was arranged in a Completely Randomized Design with four replications. Two seeds were sown per pot for each crop and thinned to one plant a week after seedling emergence. The plants were allowed to grow for eight weeks (before uprooting) during which time the crops were watered on a regular basis to field capacity. The harvested biomass from the cowpea and pearl millet crops were oven dried and tissue nitrogen determined. Nitrogen fixed by cowpea was calculated based on the Nitrogen Difference Method of Unkovich et al. (2008). Total $\mathrm{N}$ accumulated by $\mathrm{N}_{2}$-fixing plant and non $\mathrm{N}_{2}$-fixing plant were compared with the assumptions that: 1) $\mathrm{N}_{2}$-fixing legumes and non-fixing pearl millet (reference crop) plant use similar amounts of soil mineral $\mathrm{N}_{2} ; 2$ ) $\mathrm{N}$ content of the non $\mathrm{N}_{2}$-fixing plant represents the amount of soil mineral $\mathrm{N}$ available for plant growth. Total $\mathrm{N}$ in the $\mathrm{N}_{2}$ fixed was calculated as the difference in uptake of $\mathrm{N}$ of the $\mathrm{N}_{2}$ fixing and reference plants multiplied by a factor of 1.5 (Unkovich et al., 2008). This modification to the original formula was to account for the below-ground $\mathrm{N}$ for the legumes. Therefore, $\mathrm{N}_{2}$ fixed $=\left(\mathrm{N}\right.$ yield $\mathrm{N}_{2}$-fixing plant $-\mathrm{N}$ yield reference plant) $\times 1.5$.

\subsection{Statistical Analysis}

Data were collected and managed in Microsoft EXCEL software. Statistical analysis was carried out using the SAS package version 9.3. (2011). The results of the soil tests and the fixed nitrogen were analyzed using Analysis of Variance (ANOVA) to compare the effects of rotation and fertilizer applications at $95 \%$ confidence level. Means were separated using the Least Significant Difference (LSD) method at 95\% confidence level.

\section{Results}

\subsection{Effects of the Maize Cowpea Rotation on Selected Soil Chemical Properties}

\subsubsection{Soil $\mathrm{pH}$}

The soil pH ranged from 5.0-5.28 across treatments. While the results indicated non-significant differences in the soil $\mathrm{pH}$ among the treatments, the maize monocrop had higher $\mathrm{pH}$ levels than the maize-cowpea rotation at each fertilizer level (Table 1).

Table 1. Effects of maize-cowpea rotation on soil reaction, total nitrogen and soil organic carbon

\begin{tabular}{llll}
\hline Cropping type & $\begin{array}{l}\text { Soil reaction } \\
(\mathrm{pH} \mathrm{CaCl} 2)\end{array}$ & $\begin{array}{l}\text { Nitrogen } \\
(\mathrm{N} \%)\end{array}$ & $\begin{array}{l}\text { Organic Carbon } \\
(\mathrm{OC} \%)\end{array}$ \\
\hline Maize-cowpea rotation + fertilizer & $5.0^{\mathrm{a}}$ & $0.028^{\mathrm{b}}$ & $0.48^{\mathrm{a}}$ \\
Maize-cowpea rotation - fertilizer & $5.1^{\mathrm{a}}$ & $0.048^{\mathrm{a}}$ & $0.75^{\mathrm{a}}$ \\
Maize monocropping + fertilizer & $5.1^{\mathrm{a}}$ & $0.045^{\mathrm{a}}$ & $0.73^{\mathrm{a}}$ \\
Maize monocropping - fertilizer & $5.28^{\mathrm{a}}$ & $0.050^{\mathrm{a}}$ & $0.72^{\mathrm{a}}$ \\
Least Significant Difference (LSD) & 0.29 & 0.01 & 0.31 \\
Coefficient of Variation (CV\%) & 3.69 & 22 & 29.7 \\
\hline
\end{tabular}

Note. * Means followed by the same letter within a column are not statistically different at $95 \%$ confidence level.

\subsubsection{Total Nitrogen and Soil Organic Carbon}

Soil organic carbon ranged from 0.48 to $0.75 \%$ in the maize-cowpea rotation and maize mono-crop fields (Table 1). The results indicated non-significant differences among treatments; the maize-rotation with fertilizer application showed the least soil organic carbon content. There was no obvious pattern in the accumulation of soil organic carbon among the different treatments.

Results indicated that total nitrogen varied among treatments. Nitrogen levels across the fields ranged from 0.028 to $0.05 \%$. Just like soil organic carbon, total nitrogen was lowest in the maize-cowpea rotation with fertilizer application. 
Overall, the maize-cowpea rotation with fertilizer application had the lowest $\mathrm{pH}$, total nitrogen and soil organic carbon. The results indicated a strong and positive relationship between soil organic carbon and total nitrogen $\left(\mathrm{r}^{2}\right.$ $=0.9450$; data not shown).

\subsubsection{Micronutrients and Available Phosphorus}

The levels of zinc in the soil ranged from 2 to $3 \mathrm{mg} / \mathrm{kg}$ across the fields; while those of copper ranged from 5.0 to $6.8 \mathrm{mg} / \mathrm{kg}$. The highest quantity of copper was recorded from the maize-cowpea rotation where fertilizer was applied, however, results indicated that there were non-significant differences among the treatments $(P \geq 0.05)$. Manganese levels in the soil ranged from 186.3 to $227 \mathrm{mg} / \mathrm{kg}$. The highest quantity of manganese was recorded from the maize-cowpea rotation without fertilizer application, while the lowest quantity of manganese was from the maize monocropping with fertilizer application. The levels of iron in the soil varied from 66.8 to $86.8 \mathrm{mg} / \mathrm{kg}$. The highest quantity of iron was recorded from the maize-cowpea rotation with fertilizer applied while the lowest quantity was observed from soils from the maize monocropping with fertilizer application. The levels of the micronutrients zinc, copper, manganese and iron were very weakly influenced by soil reaction $(\mathrm{pH})$ with correlation coefficients of $0.0052,0.0489,0.0027$, and 0.00295 , respectively (data not shown). Sulphur and available phosphorus ranged from 12.7 to 28.2 and 8.8 to $18 \mathrm{mg} / \mathrm{kg}$ across treatments, respectively. The results indicated that there were significant differences among the treatments. For both nutrients, the highest levels were observed in the maize-cowpea rotation (MC) and the maize monocropping (MM) with fertilizer application, while the lowest was recorded from the maize monocropping without fertilizer. Fertilizer application therefore influenced levels of both nutrients.

Table 2. Micronutrient levels in soils due to maize-cowpea rotation under conservation farming and maize mono-cropping

\begin{tabular}{lllll}
\hline Cropping type & $\mathrm{Zn}(\mathrm{mg} / \mathrm{kg})$ & $\mathrm{Cu}(\mathrm{mg} / \mathrm{kg})$ & $\mathrm{Mn}(\mathrm{mg} / \mathrm{kg})$ & $\mathrm{Fe}(\mathrm{mg} / \mathrm{kg})$ \\
\hline Maize-cowpea rotation + fertilizer & $3^{\mathrm{a}}$ & $6.8^{\mathrm{a}}$ & $219.8^{\mathrm{a}}$ & $86.8^{\mathrm{a}}$ \\
Maize-cowpea rotation - fertilizer & $3^{\mathrm{a}}$ & $5.3^{\mathrm{a}}$ & $227^{\mathrm{a}}$ & $80^{\mathrm{ab}}$ \\
Maize monocropping + fertilizer & $2^{\mathrm{b}}$ & $5^{\mathrm{a}}$ & $186.3^{\mathrm{a}}$ & $66.8^{\mathrm{b}}$ \\
Maize monocropping - fertilizer & $2.8^{\mathrm{a}}$ & $6^{\mathrm{a}}$ & $214.5^{\mathrm{a}}$ & $80.3^{\mathrm{ab}}$ \\
Least Significant Difference (LSD) & 0.74 & 1.75 & 73.7 & 15.3 \\
Coefficient of Variation (\%) & 17.8 & 19.8 & 22.6 & 12.7 \\
\hline
\end{tabular}

Note. ${ }^{*}$ Means followed by the same letter within a column are not statistically different at $95 \%$ confidence level.

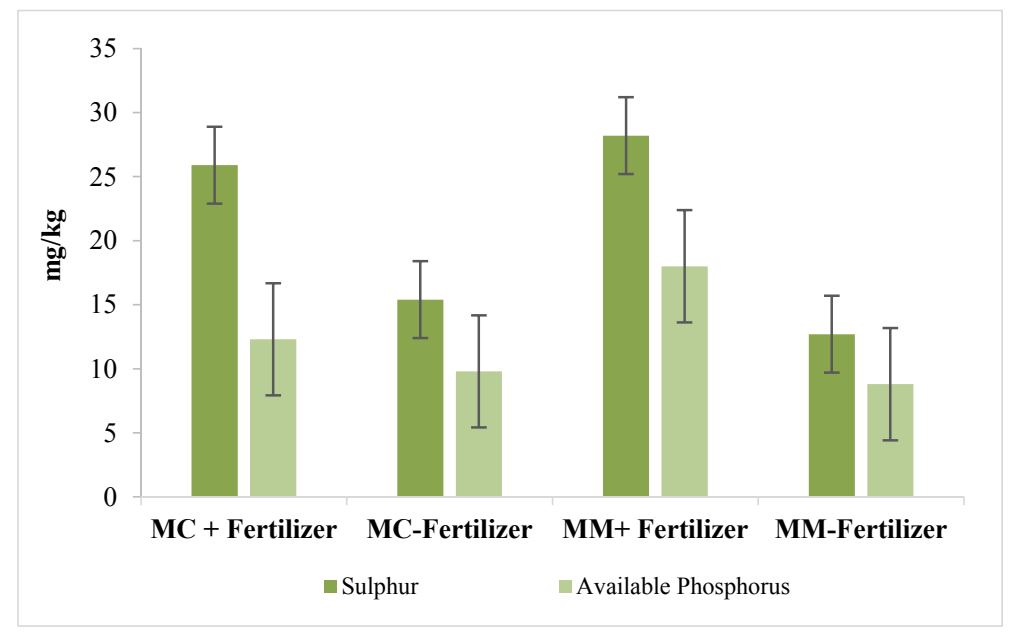

Figure 1. Concentrations of soil Sulphur and available phosphorus in maize-cowpea rotation and maize monocropping 


\subsubsection{Exchangeable Bases: Potassium, Sodium, Calcium and Magnesium}

Table 3 presents the results of exchangeable bases as influenced by the maize-cowpea rotation and maize monocropping. Calcium, magnesium, and potassium concentrations ranged from 4.0 to $4.59,2.81$ to 3 , and 0.26 to $0.47 \mathrm{cmol}(+) / \mathrm{kg}$, respectively. Sodium, though not a plant nutrient, was also determined and its levels ranged from 0.06 to $0.07 \mathrm{cmol}(+) / \mathrm{kg}$ across cropping systems and fertilizer applications. Significant differences were only observed in potassium levels among treatments; the levels of calcium, magnesium and potassium were generally higher under maize-cowpea rotation than in the maize monocropping.

Table 3. Concentrations of exchangeable bases in soils under maize cowpea rotation and maize monocrop in conservation farming

\begin{tabular}{lllll}
\hline Cropping type & $\mathrm{Ca}(\mathrm{cmol}(+) / \mathrm{kg})$ & $\mathrm{Mg}(\mathrm{cmol}(+) / \mathrm{kg})$ & $\mathrm{K}(\mathrm{cmol}(+) / \mathrm{kg})$ & $\mathrm{Na}(\mathrm{cmol}(+) / \mathrm{kg})$ \\
\hline Maize-cowpea rotation + fertilizer & $4.59^{\mathrm{a}}$ & $3^{\mathrm{a}}$ & $0.41^{\mathrm{ab}}$ & $0.065^{\mathrm{a}}$ \\
Maize-cowpea rotation - fertilizer & $4.31^{\mathrm{a}}$ & $2.94^{\mathrm{a}}$ & $0.47^{\mathrm{a}}$ & $0.065^{\mathrm{a}}$ \\
Maize monocropping + fertilizer & $4.0^{\mathrm{a}}$ & $2.81^{\mathrm{a}}$ & $0.26^{\mathrm{b}}$ & $0.068^{\mathrm{a}}$ \\
Maize monocropping - no fertilizer & $4.0^{\mathrm{a}}$ & $2.88^{\mathrm{a}}$ & $0.33^{\mathrm{ab}}$ & $0.06^{\mathrm{a}}$ \\
Least Significant Difference $(\mathrm{LSD})$ & 0.9732 & 0.7095 & 0.1595 & 0.0277 \\
Coefficient of Variation $(\mathrm{CV} \%)$ & 14.9 & 15.8 & 28.2 & 27.9 \\
\hline
\end{tabular}

Note. * Means followed by the same letter within a column are not statistically different at $95 \%$ confidence level.

Figure 2 below shows percent decline in the concentration of the exchangeable bases from the baseline at the beginning of the rotation. The results show that after 4 years of rotation and monocropping, calcium and magnesium levels declined by a range of 31.2 to $40 \%$ across treatments.

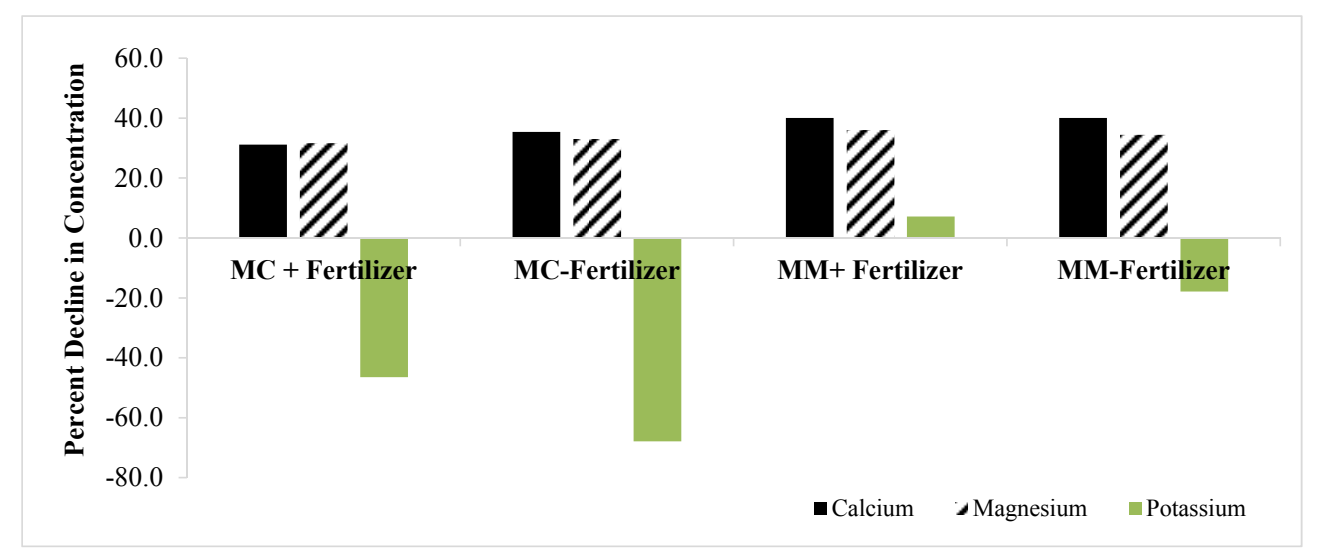

Figure 2. Percent change in calcium, magnesium and potassium due to maize-cowpea rotation and maize monocropping over 4 years of practice (Negative values indicate an increase)

On the other hand, levels of potassium increased in both maize-cowpea rotations as well as in the maize monocrop without fertilizer application. The greatest change was in the maize-cowpea rotations with 46.4 and $67.9 \%$ increase, respectively, from the baseline $(0.28 \mathrm{cmol}(+) / \mathrm{kg})$. Soil reaction did not change from the baseline of $\mathrm{pH} 5.2$ after 4 years of practice.

\subsection{Effects of the Maize Cowpea Rotation on Soil Physical Properties}

\subsubsection{Bulk Density \& Porosity}

In the maize cowpea rotation and maize mono-crop, soil bulk densities ranged from 1.32 to $1.39 \mathrm{~g} / \mathrm{cm}^{3}$ without any significant differences $(\mathrm{p}>0.05)$. Total porosities ranged from 47.5 to $49.8 \%$ with non-significant differences among the treatments. 


\subsubsection{Infiltration Rates \& Plant Available Water}

The infiltration rates ranged from 0.15 to $0.20 \mathrm{~cm} / \mathrm{min}$ without any significant differences among the treatments (Table 4). The plant available water ranged from 0.18 to $0.25(\mathrm{v} / \mathrm{v}) \mathrm{cm}$, and with significant differences between maize-cowpea rotation and maize monocropping without fertilizer $(\mathrm{p}<0.05)$.

Table 4. Effects of the Maize-cowpea rotation on bulk density, total porosity, Infiltration rate and plant available water

\begin{tabular}{lllll}
\hline Cropping type & $\begin{array}{l}\text { Bulk density } \\
\left(\mathrm{g} / \mathrm{cm}^{3}\right)\end{array}$ & $\begin{array}{l}\text { Total Porosity } \\
(\%)\end{array}$ & $\begin{array}{l}\text { Infiltration Rate } \\
(\mathrm{cm} / \mathrm{min})\end{array}$ & $\begin{array}{l}\text { Plant Available Water } \\
(\mathrm{v} / \mathrm{v}) \mathrm{cm}\end{array}$ \\
\hline Maize-cowpea rotation + fertilizer & $1.32^{\mathrm{a}}$ & $49.0^{\mathrm{a}}$ & $0.15^{\mathrm{a}}$ & $0.23^{\mathrm{ab}}$ \\
Maize-cowpea rotation - fertilizer & $1.39^{\mathrm{a}}$ & $47.5^{\mathrm{a}}$ & $0.16^{\mathrm{a}}$ & $0.25^{\mathrm{a}}$ \\
Maize monocropping + fertilizer & $1.37^{\mathrm{a}}$ & $48.1^{\mathrm{a}}$ & $0.18^{\mathrm{a}}$ & $0.24^{\mathrm{ab}}$ \\
Maize monocropping - fertilizer & $1.33^{\mathrm{a}}$ & $49.8^{\mathrm{a}}$ & $0.20^{\mathrm{a}}$ & $0.18^{\mathrm{b}}$ \\
Least Significant Difference (LSD) & 0.1261 & 4.77 & 0.1566 & 0.0618 \\
Coefficient of Variation (CV\%) & 6.0 & 6.37 & 59.8 & 17.9 \\
\hline
\end{tabular}

Note. ${ }^{*}$ Means followed by the same letter within a column are not statistically different at $95 \%$ confidence level.

\subsection{Effects of the Maize Cowpea Rotation on Selected Soil Biological Properties}

\subsubsection{Soil Microbial Biomass}

Soil microbial biomass ranged from 0.19 to 0.45 to $\mathrm{mg} \mathrm{C} / \mathrm{g}$ of soil. Soil microbial biomass was significantly higher in maize monocropping than in the maize-cowpea rotation soils (Figure 3). The results indicated a very weak correlation between soil microbial biomass with soil organic matter $\left(\mathrm{r}^{2}=0.1667\right)$. On the other hand, soil reaction was also positively but moderately correlated with soil microbial biomass $\left(r^{2}=0.5334\right)$.

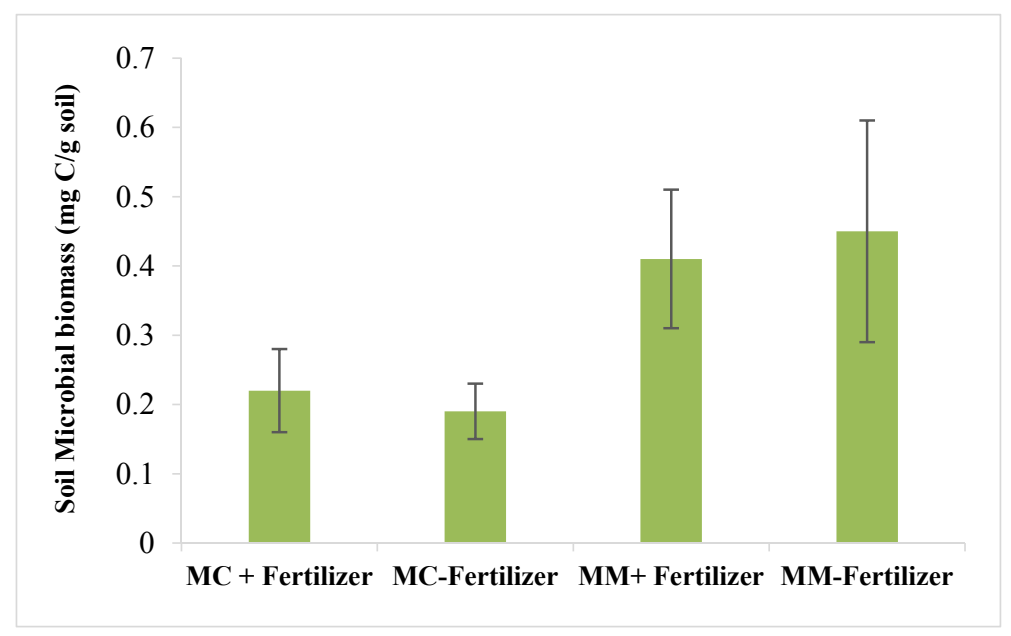

Figure 3. Soil microbial biomass under maize-cowpea rotation and maize monocropping

\subsubsection{Biological Nitrogen Fixation of Cowpea in Soils Under Maize-Cowpea Rotation and Maize Monocropping}

Biological nitrogen fixation in cowpea under greenhouse conditions ranged from 0.63 to $1.12 \%$ tissue $\mathrm{N}$. While fertilizer application seemed to depress biological nitrogen in soils, there were non-significant differences from the unfertilized systems. 


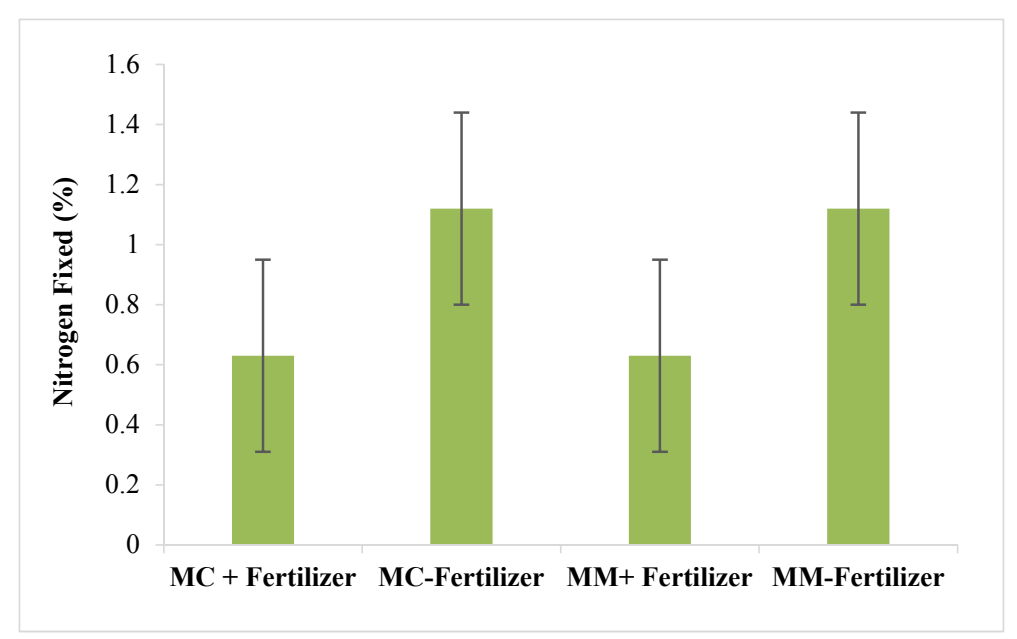

Figure 4. Biological nitrogen fixation of cowpea in soils under maize-cowpea rotation and monocropping

\section{Discussion}

The effect of maize-cowpea rotations depended on the selected soil chemical, physical and biological characteristic. Rotation of maize with cowpea did not alter soil $\mathrm{pH}$ regardless of fertilizer application. Our results are at variance with previous works that have shown that soil $\mathrm{pH}$ can be affected by crop rotation through rhizospheric processes, crop residue decomposition and microbial respiration (Hulugalle \& Weaver, 2005; Muthoni \& Kabira, 2010). While the difference in soil pH due to fertilizer application was non-significant, the use of ammonium-based $\mathrm{N}$ mineral fertilizers has been shown to cause soil acidification resulting in lower $\mathrm{pH}$ levels (Sakala, Cadisch, \& Giller, 2000; Aziz et al., 2011). The pH range of 5.0 to 5.28 was outside the optimum for cowpea growth and development (Joe \& Allen, 2008), thus suggesting a need for liming. In this study, the levels of soil organic carbon were below the critical limit of $1.5 \%$ for crop productivity (Fairhurst, 2012). The low soil organic carbon levels across the rotations can partially be attributed to the low diversity of crops under rotation (Horwath, 2006). This would, therefore, suggest that a variety of crops should be included in order to maintain or enlarge active soil carbon pools that provide a steady supply of available nutrients for each crop in the rotation. Since soil types, climatic limitations, and economics are at play, many growers are often limited by the types of crops that can be included in a rotation. Most soils contain 0.2-0.3\% nitrogen (van Straaten, 2007. In this study, all the levels of nitrogen were below the optimal range of $0.2-0.3 \%$. The nitrogen levels across the fields revealed that single rotations can have reductive effects, especially when coupled with the addition of fertilizers.

The critical limit of zinc in soils lies between $15-20 \mathrm{mg} \mathrm{kg}^{-1}$ (van Straaten, 2007). This means that all the zinc soil levels were insufficient for crop production. While the levels of zinc and iron are strongly influenced by soil reaction in general, the results of this study did not indicate such a relationship. Availability of zinc tends to vary due to either intensive conventional farming, growing of high yielding varieties, application of high analysis NPK fertilizers against non-use of zinc fertilizers and reduced or non-use of organic manures (Behera et al., 2008). On the other hand, the results suggest that the levels of both sulphur and phosphorus were sufficient for crop production as the critical levels fall in the range of 10 to $12 \mathrm{mg} / \mathrm{kg}$. Repeated application of fertilizer could give rise to residual sulphur and phosphorus, therefore explaining why the application of fertilizer to the soil could have resulted in higher levels of sulphur and phosphorus in the soil. The fertilizer used in this study contained $6.5 \% \mathrm{~S}$ and $20 \% \mathrm{P}_{2} \mathrm{O}$, thus accouting for the observed increase. While the soil $\mathrm{pH}$ in the current study ranged from 5.0 to 5.28 , which is outside the optimum for phosphorus availability, this nutrient was still sufficient for crop production. The increase in the levels of potassium observed in soils where maize was rotated with cowpea is in agreement with earlier findings by Govaerts et al. (2008). It is rather surprising that when compared to the baseline, the concentration of potassium increased the most in the maize-cowpea rotations and that the application of the NPK fertilizer tended to reduce its levels. This contradicts other reports that legumes tend to reduce rhizospheric exchangeable cations, including potassium, due high uptake to meet plant demands but agrees that monocropping contributes to significant reduction in soil exchangeable bases (Bationo, Waswa, Kihara, \& Kimetu, 2007). 
The bulk densities recorded from this study were below $1.45 \mathrm{~g} / \mathrm{cm}^{3}$. At this bulk density, aeration and water movements and good plant root relationships with soil are promoted (Rasaily, Li, He, Wang, \& Lu, 2012). The abscence of differences in bulk densities among the soils from different treatments is in agreement with earlier findings that there are no clear effects observable on bulk density in less than 10 years of practice (Verhulst et al., 2010). This observation, could therefore be extended to total porosity and water infiltration rates. It is difficult to attribute the differences in plant available water between maize-cowpea rotation and maize monocrop without fertilizers to organic matter accumulation, which was not significantly different between the two.

The highest microbial biomass was recorded from the maize monocrop. Rhizospheric microbial community is strongly influenced by the levels of soil organic matter, plant species, and composition of root exudates which differ and vary among plant species. Since the study did not characterize the nature and composition of the root exudates, one could speculate that factors associated with either the rhizosphere of cowpea or maize had a strong influence on microbial biomass. This might suggest that there is a need to understand these rhizospheric factors if appropriate crop combinations have to be included in rotations in order to get the maximum benefits with respect to biological characteristics. The amount of nitrogen (N\% fixed) was not influenced by rotation but was reduced by the application of fertilizer. In addition, the range of 5.0 to 5.28 was outside the optimum $\mathrm{pH}$ for cowpea growth, development and nitrogen fixation (Joe \& Allen, 2008). The results suggest that in order to get the full benefit of having cowpea in a rotation, there is a need to lime the soil to raise the $\mathrm{pH}$ but also to minimize the use of nitrogen containing fertilizers which might affect the formation of the symbiosis between the rhizobia and the host, and subsequent nitrogen fixation.

\section{Conclusion}

The results suggest that maize-cowpea rotations and addition of fertilizer have influences that differ depending on a particular soil chemical or biological attribute. It can be concluded that rotating maize and cowpea has no influence on soil reaction, soil organic carbon, micronutrients, and exchangeable bases except for potassium. However, the addition of $100 \mathrm{~kg} / \mathrm{ha}$ of NPK (10:20:10) plus 6.5\% sulphur fertilizer to the maize-cowpea rotation reduces total nitrogen, while increasing the levels of sulphur and phosphorus in both the rotation and maize monocrop. The soil bulk density, total porosity and infiltration rate are not influenced by the maize-cowpea rotation with or without amendment with fertilizers. Rotating maize with cowpea without the addition of fertilizer can result in an increase in plant available water, an observation needing further study. It can also be concluded that maize-cowpea rotations can reduce microbial biomass, regardless of fertilizer amendment, thus suggesting a need to understand maize and cowpea rhizopheric attributes affecting microbial biomass levels. Under the current conditions, the amount of biologically fixed nitrogen by cowpea is reduced by the application of fertilizer but not influenced by the rotation. Since these findings are based on four-year crop rotation, it is being recommended that further work be conducted to continue monitoring soil so as to factor in the effect of length of time.

\section{Acknowledgements}

Gratitude is extended to IITA (Zambia) who funded the research and Golden Valley Agricultural Research Trust (GART) who hosted the trials.

\section{References}

Aziz, I., Ashraf, M., Mahmood, T, T., \& Islam, K. R. (2011). Crop rotation impact on soil quality. Pak. J. Bot., 43(2), 949-960. https://doi.org/10.1080/00103624.2016.1146749

Barker, A., \& Pilbeam, D. (2006). Plant Nutrition. CRC Press, USA. https://doi.org/10.1201/9781420014877

Bationo, A., Waswa, B., Kihara, J., \& Kimetu, J. (2007). Advances in Integrated Soil Fertility Management in Sub-Saharan Africa: Challenges and opportunities. Springer Publishers Netherlands. https://doi.org/ 10.1007/978-90-481-2543-2_1

Beare, M. H., Cabrera, M. L., Hendrix, P. F., \& Coleman, D. C. (1994). Aggregate-protected and unprotected organic matter pools in conventional and no-tillage soils. Soil Science Society of America Journal, 58(3), 787-795. https://doi.org/10.1007/978-90-481-3585-1197

Behera, K. S., Singh, D., Diwiredi, B. S., Singh, S., Kumar, K., \& Rana, D. S. (2008). Distribution of fractions of Zinc and their contribution towards availability and plant uptake of zinc under long term maize and wheat cropping on inceptisol. Australian Journal of Soil Research, 46, 83-89. https://doi.org/10.1071/SR07073 
Berc, J., Bruce, J., Easterling, D., Groisman, P. Y., Hatfield, J., Hughey, B., ... Spaeth, K. (2003). Conservation Implications of Climate Change: Soil Erosion and Runoff from Cropland. USA, Iowa: Soil and Water Conservation Society.

Bremner, J. M., \& Mulvaney, C. S. (1982). Nitrogen total. In A. L. Page, R. H. Miller \& D. R. Keeney (Eds.), Methods of Soil Analysis, Part 2: Chemical and Microbiological Properties (2nd ed., Agronomy, 9, pp. 595-624). Am. Soc. Agronomy.

Conservation Farming Unit (CFU). (2007a). Conservation Farming and Conservation Agriculture Handbook for Hoe Farmers in Agro-Ecological Regions I and IIa. Lusaka: ZNFU, CFU.

Conservation Farming Unit (CFU). (2007b). Conservation Farming and Conservation Agriculture Handbook for Ox Farmers in Agro-Ecological Regions I and IIa. Lusaka: ZNFU, CFU.

Day, P. R. (1965). Particle size fractionation and particle size analysis. In C. A. Black (Ed.), Methods of Soil Analysis (Agronomy, 9, pp. 545-567). Am. Soc. Agron. Inc.

Fairhurst, T. (2012). Handbook for integrated soil fertility management. Africa Soil Health Consortium, Nairobi, Kenya.

Giller, K. E., Witter, E., Corbeels, M., \& Tittonel, P. (2009). Conservation agriculture and small holder farming in Africa: The heretics view. Field Crops Research, 11(1), 23-34. https://doi.org/10.1016/j.fcr.2009.06.017

Govaerts, B., Mezzalama, M., Unno, Y., Sayre, K. D., Luna-Guide, M., Vanherck, K., ... Deckers, J. (2008). Influence of tillage, residue management and crop rotation on soil microbial biomass and catabolic diversity. Applied Soil Ecology, 37, 18-30. https://doi.org/10.1016/j.apsoil.2007.03.006

Haggblade, S., Kabwe, S., \& Christine, P. (2011). Productivity Impact of Conservation Farming on Small Holder Cotton Farmers in Zambia. FSRP Working Paper No. 47. https://doi.org/10.1016/j.agsy.2014.08.001

Horwath, W. R. (2006). C. cycling and formation of soil organic matter. In W. Chesworth (Ed.), Encyclopedia of soil science and technology. Amsterdam: Kluwer.

Hulugalle, N. R., \& Weaver, T. B. (2005). Short-term variations in chemical properties of vertisols as affected by amounts, carbon/nitrogen ratio and nutrient concentration of crops residues. Communication in Soil Science and Plant Analysis, 36, 1449-1446. https://doi.org/10.1081/CSS-200058489

Joe, W. H., \& Allen, J. R. (2008) Effect of soil pH on plant growth and nodulation of cowpea. Communications in Soil Science and Plant Analysis, 11(11), 1077-1085. https://doi.org/10.1080/00103628009367106

Kassem, A., \& Nannipieri, P. (1995). Methods in applied soil microbiology and biochemistry. Academy Press Limited, US.

Mclean, E. O. (1982). Soil pH and lime requirement. In A. L. Page, R. H. Miller, \& D. R. Keeney (Eds.), Methods of soil analysis: Part 2-Chemical and microbiological properties (2nd ed., Agronomy, 9, pp. 99-223). Am. Soc. Agronomy.

Munyinda, K., Yamba, F. D., \& Walimwipi, R. (2012). Bioethanol Potential and Production in Africa: Sweet Sorghum as a Complementary Feedstock. Bionergy for Sustainable Development in Africa (pp. 81-91). Springer. https://doi.org/10.1007/978-94-007-2181-4_8

Muthoni, J., \& Kabira, N. J. (2010). Effects of crop rotation on soil micronutrients and pH in potato producing areas in Kenya: case study of KARI Tigoni station. Academic Journals, 1(9), 227-233.

Nyagumbo, I. (2008). A Review of Experiences and Developments towards Conservation Agriculture and Related Systems in Zimbabwe. In T. Goddard, M. Zoebisch, Y. Gan, W. Ellis, A. Watson, \& S. Sombatpanit (Eds.), No-Till Farming (Special Publication No. 3, pp. 345-372). World Association of Soil and Water Conservation: Bangkok, Thailand. https://doi.org/10.1007/s00267-013-0215-5

Rasaily, R. G., Li, H., He, J., Wang, Q., \& Lu, C. (2012). Influence of no tillage-controlled traffic system on soil physical properties on double cropping area of North China Plain. African Journal of Biotechnology, 11(4), 856-864. https://doi.org/10.5897/AJB11.22

Reeves, D. W. (1994). Cover crops and Crop rotations. In J. L. Hatfield, \& B. A. Stewart (Eds.), Advances in Soil Science-Crop Residues Management (pp. 125-172). Lewis Publishers, CRC Press, Boca Raton, FL, USA. 
Rhodes, J. D. (1982). Soluble salts. In A. L. Page, R. H. Miller, \& D. R. Keeney (Eds.), Methods of soil analysis Part 2: Chemical and Microbiological Properties (2nd ed., Agronomy, 9, pp. 149-157). American Society of Agronomy.

Riedell, W. E., Pikul, J. L., Jaradat, A. A., \& Schumacher, T. E. (2009). Crop Rotation and Nitrogen Input Effects on Soil Fertility, Maize Mineral Nutrition, Yield, and Seed Composition. Agron. J., 101, 870-879. https://doi.org/10.2134/agronj2008.0186x

Sakala, W. D., Cadisch, G., \& Giller, K. E. (2000). Interactions between residues of maize and pigeon pea and mineral N fertilizers during decomposition and N mineralization. Soil Biol. Biochem., 32, 679-688. https://doi.org/10.1371/journal.pone.0103720

Seiter, S., \& Horwath, W. R. (2004). Strategies for managing soil organic matter to supply plant nutrients. In F. Magdoff \& R. R. Weil (Eds.), Soil organic matter in sustainable agriculture, Advances in Agroecology (Series Vol. 11, pp. 269-294). Boca Raton: CRC. https://doi.org/10.1201/9780203496374.ch9

Thierfelder, C., \& Wall, P. C. (2009). Effects of Conservation Agriculture Techniques on Infiltration and soil water content in Zambia and Zimbabwe. Soil and Tillage Research, 105, 217-227. https://doi.org/ 10.1016/j.still.2009.07.007

Thierfelder, C., \& Wall, P. C. (2012). Effects of conservation agriculture on soil quality and productivity in contrasting agro-ecological environments of Zimbabwe. Soil Use and Management, 28(2), 209-220. https://doi.org/10.1111/j.1475-2743.2012.00406.x

Thomas, G. W. (1982). Exchangeable Cations. In Al Page et al. (Eds.), Methods of soil Analysis (pp. 154-157). Am. Soc. Agronomy.

Tisdale, L. S., Nelson, L. W., \& Beaton, D. J. (1985). Soil Fertility and Fertilizers (4th ed.). Macmillan Publishing Company, New York.

Traore, O., Traole, K., Bado, V. B., \& Lompo, D. J. P. (2007). Crop rotations and soil amendments: Impacts on cotton and maize production in cotton-based system in Western Burkina Faso. Int. J. Bio. Chem. Sci., 1(2), 143-150. https://doi.org/1015413/ajar.2016.1210

Unkovich, M., Herridge, D., Peoples, M., Cadisch, G., Boddey, B., Giller, K., ... Chalk, P. (2008). Measuring plant-associated nitrogen fixation in agricultural systems. Australian Centre for International Agricultural Research (ACIAR), Australia.

Van Straaten, P. (2007). Agrogeology: The use of rocks for crops. Ontario, Canadá: Enviroquest.

Verhulst, N., Govaerts, B., Verachtertb, E., Castellanos, A. N., Mezzalamaa, M., Walla, P. C., \& Sayrea, K. D. (2010). Conservation agriculture, improving soil quality for sustainable production systems. International Maize and Wheat Improvement Centre (CIMMYT), Mexico.

Zimbabwe Conservation Agriculture Task Force. (2009). Farming for the future: A guide to conservation agriculture in Zimbabwe. Zimbabwe Conservation Agriculture Task Force.

\section{Copyrights}

Copyright for this article is retained by the author(s), with first publication rights granted to the journal.

This is an open-access article distributed under the terms and conditions of the Creative Commons Attribution license (http://creativecommons.org/licenses/by/4.0/). 